\title{
Spatial features of rain frequency change and pollution and associated aerosols
}

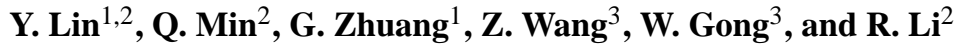 \\ ${ }^{1}$ Department of Environmental Science and Engineering, Fudan University, China \\ ${ }^{2}$ Atmospheric Sciences Research Center, State University of New York, USA \\ ${ }^{3}$ Department of Environmental Science, Wuhan University, China
}

Received: 1 February 2011 - Published in Atmos. Chem. Phys. Discuss.: 14 March 2011

Revised: 11 May 2011 - Accepted: 11 July 2011 - Published: 3 August 2011

\begin{abstract}
A spatial-temporal analysis has been conducted using satellite observed distributions of rain frequency, $\mathrm{NO}_{2}$ concentration and aerosol, with focus on the spring season in East Asia. As $\mathrm{NO}_{2}$ is a key precursor of secondary aerosols, especially in urban areas, an increase of $\mathrm{NO}_{2}$ emission is generally accompanied by an increase of fine aerosol particles. Comparison between trends in rain frequency and in precipitation amount shows that the changes in precipitation are more due to changes in precipitation occurrence than in precipitation amount. The overall feature emerged from the region-by-region analyses is that there is an inverse relationship between the rain frequency and the pollution and associated aerosols at continental scale in spring. The change in rain frequency is associated with changes in pollution-produced aerosols and long-range transport mineral dust. The inverse relationship at large temporal and spatial scales illustrates potential climatological consequence of changed pollution and aerosols on precipitation. Due to relatively short duration of observation and the potential uncertainty and bias associated with satellite measurements, more robust longer-term statistical study at various temporal and spatial scales and detailed modeling investigation are warranted to understand the physical causality of observed relationship between the rain frequency and the pollution and associated aerosols.
\end{abstract}

\section{Introduction}

Human-induced climate change has caused a redistribution of precipitation (Alpert et al., 2008; Changnon et al., 1981; Halfon et al., 2009; Lowry, 1998; van den Heever and Cotton, 2007; Zhang et al., 2007). Besides the greenhouse gases-

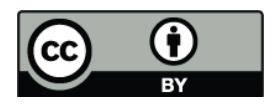

Correspondence to: Q. Min (min@asrc.albany.edu) induced global warming that intensifies the hydrological cycle (Allen and Ingram, 2002; Dell et al., 2008; Fowler and Hennessy, 1995), regional and local changes associated with urban heat island, land use change, the injection of moisture from industrial sources, and pollutant aerosols also have significant impacts on precipitation (Cotton and Pielke, 1995; Landsberg, 1981; Bornstein and Lin, 2000; Shepherd and Burian, 2003; Shepherd et al., 2002). While the former three factors tend to promote precipitation by enhancing the atmospheric updrafts and evaporation or increasing the roughness of urban surface (Chow and Chang, 1984; Hand and Shepherd, 2009; Lowry, 1998; Shepherd, 2006), the possible impacts of pollutant aerosols on precipitation remain the greatest controversy (Stevens and Feingold, 2009). Therefore, it is crucial to indentify and explain precipitation changes associated with regional and local influences, particularly pollution and associated aerosols.

Anthropogenic aerosols that increase concentrations of cloud condensation nuclei $(\mathrm{CCN})$ and ice-forming nuclei (IN) alter the main path of precipitation-forming microphysical processes and the precipitation amount (Cotton and Pielke, 1995; Ramanathan et al., 2005; Rosenfeld et al., 2008). Albrecht (1989) found that the increasing of aerosol concentration may reduce the drizzle over ocean and increase the amount of low-level cloudiness. There was less drizzle in polluted regions than in pristine regions (Heymsfield and McFarquhar, 2001; Yum and Hudson, 2002). Over urban area, the precipitation may shut off or be delayed due to the urban and industrial air pollution (Rosenfeld, 2000). Also carbonaceous aerosols absorb radiation and enhance atmospheric heating, thereby reducing the strength of updraft and associated precipitation (Ramanathan et al., 2005; Zhao et al., 2006). Small et al. (2009) suggested an evaporation-entrainment feedback associated with polluted aerosol, which may shift marginally-precipitating clouds to the non-precipitating regime. Besides most of studies that show aerosol may inhibit precipitation, there are some other

Published by Copernicus Publications on behalf of the European Geosciences Union. 
studies report that aerosol may promote precipitation through the convection invigorating and the accelerating of cloud water convert to precipitation (Koren et al., 2005; Rosenfeld et al., 2008; Stevens and Seifert, 2008; Williams et al., 2002). Furthermore, the influences of anthropogenic pollutants on precipitation are confounded by dynamic processes in various temporal and spatial scales, which heighten the need for accurate information about temporal and spatial variations in precipitation and aerosols (IPCC, 2007a; New et al., 2001; Qian et al., 2009; Yang and Lau, 2004). Few, if any, studies have reported directly observational linkage between the rain frequency and the pollution and associated aerosols at continental scale.

Heterogeneous spatial distribution of anthropogenic aerosols, which results from their short lifetime, may provide spatial signatures of anthropogenic pollution on precipitation. East Asia is characterized by a rapid increase of energy consumption accompanied by a rapid growth of population and economic activities, resulting in significant enhancement in the concentration of aerosols and pollutants (Luo et al., 2001; van der A et al., 2006). East Asia also acts as the receptor of dust from arid and semiarid regions (Sun et al., 2005; Wang et al., 2006). The incoming mineral aerosol particles mixing with local emission may accelerate the gasparticle interaction as well as serve as giant CCN. Since East Asia is the most populous region and one of the largest grain producing regions in the world, climate change, especially precipitation change, may have great consequences for the ecosystem and residents. The severe anthropogenic pollution over Asia provides the possibility and urgency to study the anthropogenic forcing on precipitation at a large scale.

Due to the large spatial and temporal variability of aerosols and precipitation, remote sensing from satellites delivers the most reliable information about their regional and global distribution. This study investigates the linkage between rain and air pollutants and associated anthropogenic aerosols from the spatial-temporal perspective by utilizing multisatellite observations over East Asia. It is believed that precipitation in the spring is less influenced by the monsoon dynamics of atmospheric general circulation (Gong and Wang, 1999). Also any precipitation change in spring will significantly impact stable crop production in the region (Tirado et al., 2010). Therefore, we will focus our study on the spring season (March, April and May).

\section{Measurements}

The Tropical Rainfall Measuring Mission (TRMM) satellite provides the first detailed and comprehensive dataset on the four-dimensional distribution of rainfall within about $36^{\circ}$ latitude. To highlight spatial-temporal characteristics of rainfall distribution, monthly rainfall dataset from TRMM Precipitation Radar (PR) at $0.5^{\circ} \times 0.5^{\circ}$ spatial grid (TSDIS, 2007; version; 3A25; source: http://daac.gsfc.nasa.gov/data/) from

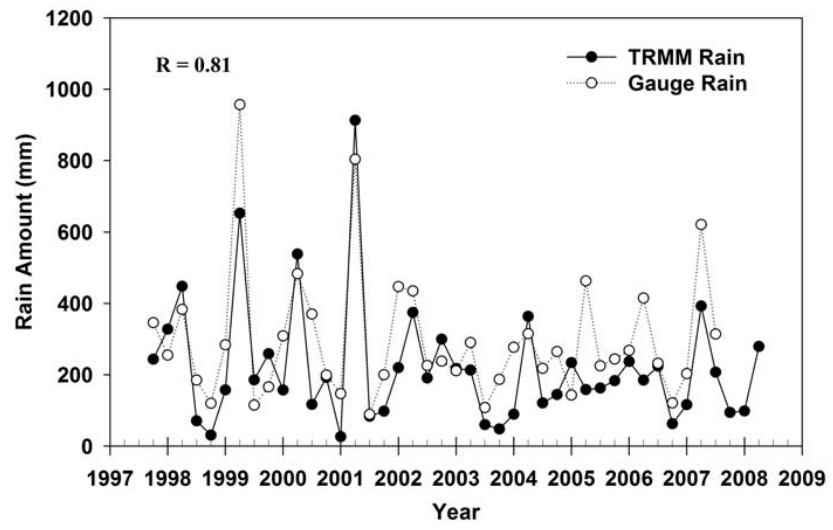

Fig. 1. Seasonal precipitation amount estimated from TRMM PR and measured from surface rain gauge from 1998 to 2009 in Shanghai.

1998 to 2009 are used in this study. In addition to the TRMM PR estimated precipitation, the surface rain gauge precipitation data (the Chinese National Meteorological Center: http://cdc.cma.gov.cn) are used to verify the satellite measurements and investigate the relationship between precipitation and air pollutants. As shown in Fig. 1, the seasonal precipitation amount estimated from TRMM PR over a $1^{\circ} \times 1^{\circ}$ grid is consistent with precipitation measurements from a surface rain gauge $\left(31^{\circ} 10^{\prime} \mathrm{N}, 121^{\circ} 26^{\prime} \mathrm{E}\right)$ in Shanghai, with correlation coefficient of 0.81 at a $95 \%$ confidence level. The comparisons at some other typical sites during 1998-2009 are list in Table 1. Good correlations are observed between the two datasets, although the precipitation amount derived from TRMM PR are more or less lower than the surface rain gauge measurement, which could be probably due to the sensitivity of PR that limits its detection of precipitation over $0.4 \mathrm{~mm} \mathrm{~h}^{-1}$. Those comparisons illustrate that precipitation estimated from PR is representative at seasonal scale or longer time scales. Given the same instrument and retrieval algorithm for TRMM PR measurements, we expect that the trend of precipitation estimated from TRMM PR is reliable.

As a marker of air pollution, tropospheric nitrogen dioxide $\left(\mathrm{NO}_{2}\right)$ has been monitored by both the Global Ozone Monitoring Experiment (GOME) and SCanning Imaging Absorption SpectroMeter for Atmospheric CHartographY (SCIAMACHY) satellites. Hence, monthly $\mathrm{NO}_{2}$ vertical column concentration from combined GOME 1998-2002 and SCIAMACHY 2003-2009 measurements (Richter et al., 2002; source: http://www.iup.uni-bremen.de/doas/data products.htm) are used to quantify air pollution changes over the same period of PR dataset. $\mathrm{NO}_{2}$ vertical column concentration from GOME and SCIAMACHY have been validated by ground-based and airborne measurements, indicating that satellite observed $\mathrm{NO}_{2}$ vertical column concentration is a good marker of local air pollution (Heue et al., 2005; Ionov et al., 2006). 
Table 1. The correlation of rain gauge and TRMM PR measured precipitation amount ( $\mathrm{mm} / \mathrm{per}$ season) at various sites over China.

\begin{tabular}{llrll}
\hline & Location & Altitude & Function & $\mathrm{R}$ \\
\hline Shanghai & $31^{\circ} 10^{\prime} \mathrm{N}, 121^{\circ} 26^{\prime} \mathrm{E}$ & $2.8 \mathrm{~m}$ & $\mathrm{PR}=0.78 \times$ Gauge -5.60 & 0.81 \\
Hangzhou & $30^{\circ} 14^{\prime} \mathrm{N}, 120^{\circ} 10^{\prime} \mathrm{E}$ & $41.7 \mathrm{~m}$ & $\mathrm{PR}=0.44 \times$ Gauge +65.6 & 0.68 \\
Changsha & $28^{\circ} 12^{\prime} \mathrm{N}, 113^{\circ} 05^{\prime} \mathrm{E}$ & $44.9 \mathrm{~m}$ & $\mathrm{PR}=0.66 \times$ Gauge +41.8 & 0.69 \\
Wuhan & $30^{\circ} 37^{\prime} \mathrm{N}, 114^{\circ} 08^{\prime} \mathrm{E}$ & $23.3 \mathrm{~m}$ & $\mathrm{PR}=0.76 \times$ Gauge +122.1 & 0.74 \\
Zhengzhou & $34^{\circ} 43^{\prime} \mathrm{N}, 113^{\circ} 39^{\prime} \mathrm{E}$ & $110.4 \mathrm{~m}$ & $\mathrm{PR}=0.57 \times$ Gauge +17.6 & 0.84 \\
Nanjing & $32^{\circ} 00^{\prime} \mathrm{N}, 118^{\circ} 48^{\prime} \mathrm{E}$ & $8.9 \mathrm{~m}$ & $\mathrm{PR}=0.94 \times$ Gauge -41.5 & 0.88 \\
Xi'an & $34^{\circ} 18^{\prime} \mathrm{N}, 108^{\circ} 56^{\prime} \mathrm{E}$ & $396.9 \mathrm{~m}$ & $\mathrm{PR}=0.57 \times$ Gauge +16.2 & 0.79 \\
Lasa & $29^{\circ} 40^{\prime} \mathrm{N}, 91^{\circ} 08^{\prime} \mathrm{E}$ & $3648.7 \mathrm{~m}$ & $\mathrm{PR}=0.22 \times$ Gauge +6.20 & 0.77 \\
\hline
\end{tabular}

Precipitation can be influenced by anthropogenic aerosols associated with pollution through their roles in cloud condensation nuclei and ice nuclei, and through the direct effect of pollution on the stability of the atmosphere. To assess the changes of aerosol loading in the atmosphere directly, aerosol optical depths from MODerate resolution Imaging Spectroradiometer (MODIS) on board the Terra Satellite (King et al., 2003) are also used. The extensive validation of MODIS aerosol products confirmed that the uncertainty of MODIS optical retrievals within $\Delta \tau= \pm 0.03 \pm 0.05 \tau$ over ocean and $\Delta \tau= \pm 0.05 \pm 0.15 \tau$ over land, which suggests that MODIS aerosol products can be used in the analysis of aerosol distribution (Chu et al., 2002; Remer et al., 2005; Kahn et al., 2009; Levy et al., 2010). Furthermore, Zhang and Reid (2009, 2010) examined biases in satellite AOD trend analysis due to radiometric calibration, cloud contamination, and sampling biases, and concluded that it is reasonable to use monthly mean AOD values from Terra/Aqua MODIS to study the decadal aerosol optical depth trend. Further, cloud fraction and cloud effective radius from MODIS/Terra are also used to identify changes of cloud properties.

In general, there are several issues for satellite observations: instrument calibration and stability, sampling bias due to satellite orbits and clear-sky/cloud/rain classification, and relatively short observation duration. Those issues may introduce biases and uncertainties to our analysis. Therefore, we carefully select the spatial domain and temporal interval for aggregating satellite data, and choose parameters that are less influenced by those issues. In particular, we focus our analysis on the spatial feature of rain frequency change induced by pollution and associated aerosols from the spatialtemporal perspective by utilizing multi-satellite observations over East Asia.

\section{Results}

Due to the relatively short lifetime of $\mathrm{NO}_{2}$ and the vertical distribution of $\mathrm{NO}_{\mathrm{x}}$ sources, $\mathrm{NO}_{2}$ columns observed from space are dominated by the $\mathrm{NO}_{2}$ concentration in the

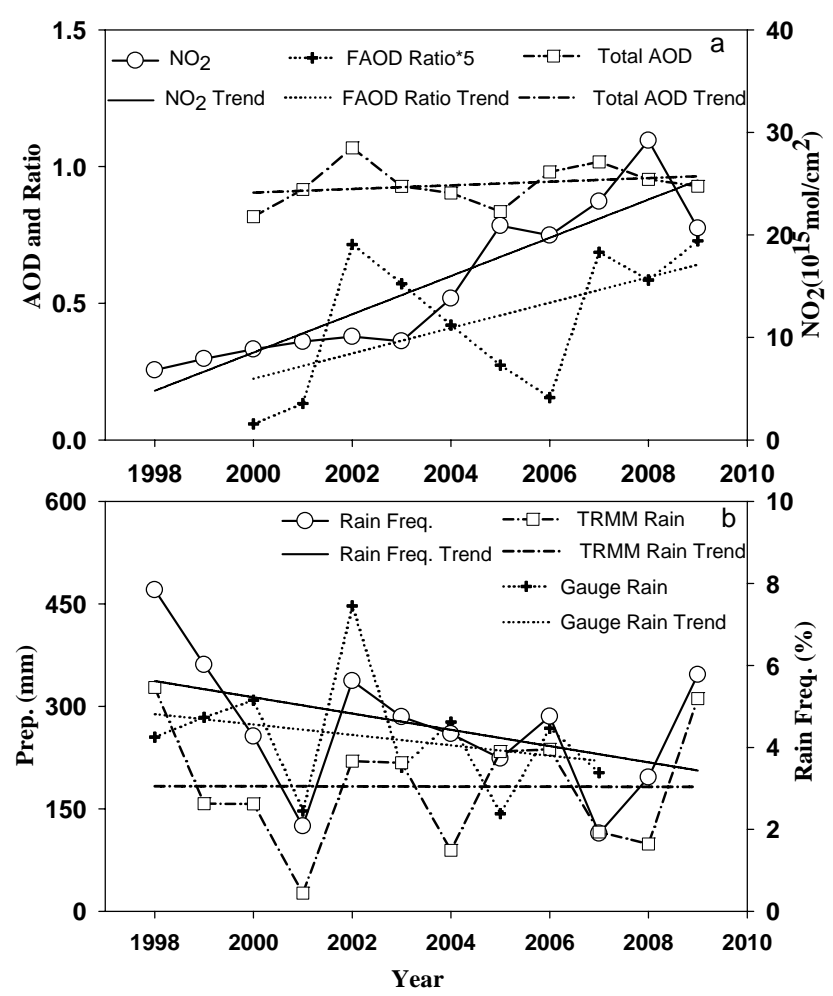

Fig. 2. (a) Time series of MODIS aerosol optical depth and satellite measured tropospheric $\mathrm{NO}_{2}$; (b) Time series of TRMM PR rain frequency and rain amount, and surface rain gauge measured precipitation from 1998 to 2009 for the $1^{\circ} \times 1^{\circ}$ grid centered at Shanghai

boundary layer and at the source (Richter et al., 2005). As shown in Fig. 2a, satellite retrieved $\mathrm{NO}_{2}$ column concentration in spring in Shanghai increased substantially from 1998 to 2009 . The linear trend in $\mathrm{NO}_{2}$ column concentration is $1.6 \times 10^{15}$ molec $\mathrm{cm}^{-2}$ per year. With respect to the reference value of $6.8 \times 10^{15}$ molec $\mathrm{cm}^{2}$ in spring 1998 , air pollution in Shanghai was almost tripled from 1998 to 2009. Nitrogen dioxide is an effective absorber of visible and near-ultraviolet solar radiation. At wavelengths below $\sim 400 \mathrm{~nm}$, photodissociation of $\mathrm{NO}_{2}$ generates $\mathrm{NO}$ and $\mathrm{O}$ 
atoms that quickly attach to molecular oxygen to form ozone. Back-reactions of $\mathrm{NO}$ with ozone and/or other radicals establish a steady state between $\mathrm{NO}$ and $\mathrm{NO}_{2}$ in the troposphere. The photodissociation of $\mathrm{NO}_{2}$ is of major importance to atmospheric chemistry in addition to that of ozone, as this process is also involved in the production of many oxidants, such as radicals $\mathrm{OH}, \mathrm{HO}_{2}, \mathrm{RO}_{2}$, which could oxidize $\mathrm{SO}_{2}$, in addition to $\mathrm{NO}_{2}$, and leads to the formation of nitric acid and sulfuric acid and, in turn, the subsequent neutralization conversions to nitrate and sulfate, the major parts of the secondary aerosols. Therefore, $\mathrm{NO}_{2}$ is a key precursor of secondary aerosols, especially in urban areas. Thus, the dramatic increase in $\mathrm{NO}_{2}$ concentration implies a substantial enhancement of atmospheric aerosol loading. Satellite retrieved AOD includes locally generated aerosols that are associated with pollution and small in size, and transported aerosols, such as dust with large size. As shown in Fig. 2a, the retrieved AOD from MODIS showed an increase in recent years, although there was large interannual variability which was mostly associated with the spring dust events and local construction activities (Wang et al., 2006). Although the retrieval of fine mode AOD is much less reliable than total AOD (Hyer et al., 2011; Kahn et al., 2009; Remer et al., 2008), the trend of fraction ratio of fine mode aerosols increased consistently with the increasing trend in $\mathrm{NO}_{2}$ concentration.

Most particles over urban areas are composed of hygroscopic salts, i.e., sulfates and nitrates (Givati and Rosenfeld, 2004), which can rapidly reach their critical size under relatively low supersaturations and act as effective CCN (Levin et al., 1996). The huge local anthropogenic emission resulting from rapid economic growth and urban development mixing with long range transported dust, therefore, lead to a high concentration of cloud condensation nuclei (CCN). It is plausible that the observed trend of $\mathrm{NO}_{2}$ in Shanghai implies an increasing trend in CCN concentration from 1998 to 2009.

Although there is a spatial-temporal mismatch between TRMM PR estimated precipitation and rain gauge measured precipitation, the decreasing trends of precipitation are consistent (Fig. 2b). Both PR and rain gauge measurements in spring show that precipitation amount was reduced from 1998 to 2009. Reduction in precipitation could be either a decrease in rain frequency or in rain rate within the $1^{\circ} \times 1^{\circ}$ grid. Small footprint and high sensitivity of TRMM PR allows us to evaluate the seasonal rain frequency at $1^{\circ} \times 1^{\circ}$ grids, defined as the ratio of raining pixels to total sampling pixels. Using such a relative parameter also minimizes the systemic bias and retrieval uncertainties of PR rain rate retrievals. Clearly, the decreasing trend of $4.38 \%$ per year in rain frequency $(0.20 \%$ per year in absolute rain frequency) is slightly greater than the decrease trend of $2.99 \%$ per year in rain amount (7.61 mm per year in absolute rain amount). It suggests that reduction in precipitation is mainly due to the suppression of rain occurrence with a slight enhancement of rain intensity.
Cloud formation is strongly controlled by meteorological conditions, such as temperature and atmospheric convection. The increased $\mathrm{NO}_{2}$ and aerosols (soot particles in particular) affect the radiative processes in the atmosphere through enhancing absorption of solar radiation and heat the atmosphere, which lead to changes in the air temperature and atmospheric stability (Ramanathan et al., 2005). If the atmosphere becomes more stable, the upward motions are depressed, and cloud formation is reduced, resulting in reduction of precipitation (Zhao et al., 2006). Furthermore, if the moisture in the atmosphere is not altered by the increase in pollution particle number concentration, the cloud droplet radius will decrease, resulting in a decrease in the precipitation efficiency (IPCC, 2007b; Ramanathan et al., 2001). The opposite trends of precipitation and air pollutants imply the possibility that the increased particles over urban areas suppress the local precipitation, particularly the rain frequency. As shown in Fig. 2b, the decreasing trend of TRMM rain frequency was larger than the decreasing trends of rain amount from both TRMM PR and surface gauge measurements. However, the inverse relations of rain frequency and precipitation to the concentrations of $\mathrm{NO}_{2}$ and aerosols at a single site for past decades can be casual, as precipitation changes are strongly influenced by changes of large scale dynamics and by other human-induced local effects. In addition to air pollutant emissions, other human-induced local changes, such as land use-change, may independently or synergistically, altering the local and regional atmosphere dynamic, modifying the precipitation clouds (Hand and Shepherd, 2009; Junkermann et al., 2009; Zhang et al., 2009). To exclude the possible influence of meteorological factors changes on specific sites, the spatial-temporal distribution of rain frequency, $\mathrm{NO}_{2}$ concentration, and aerosol loading are investigated.

Many studies suggested that there were strong increasing trends of $\mathrm{NO}_{2}$ in some regions of China and India for the past decade (Richter et al., 2005; van der A et al., 2006). As illustrated in Figs. 3a-c, those regions include the North Chinese Plain, Yangtze River Delta, Pearl River Delta, Sichuan Basin and India Ganges region where economy has been developed substantially in recent years. Since Asia monsoon is in a transition phase in spring, the stable atmospheric structure prevents dispersion of air pollutants. As expected, most of those regions have a high mean AOD with a positive trend in fine mode AOD (Figs. 3d-f). One exceptional region is around the Nepal-India border, where agriculture is the dominant economy. The $\mathrm{NO}_{2}$ concentration is very low with no significant changes and fine mode AOD showing slightly increasing trend. However, the coarse mode AOD, which is the major contribution of aerosol loading during MAM (March, April and May, pre-monsoon period) (Gautam et al., 2009b), showing a slightly decreasing trend due to reduction of the long-range transport of aerosols ranging from India and the Middle East (Carrico et al., 2003; Prasad et al., 2007; Singh et al., 2006) 

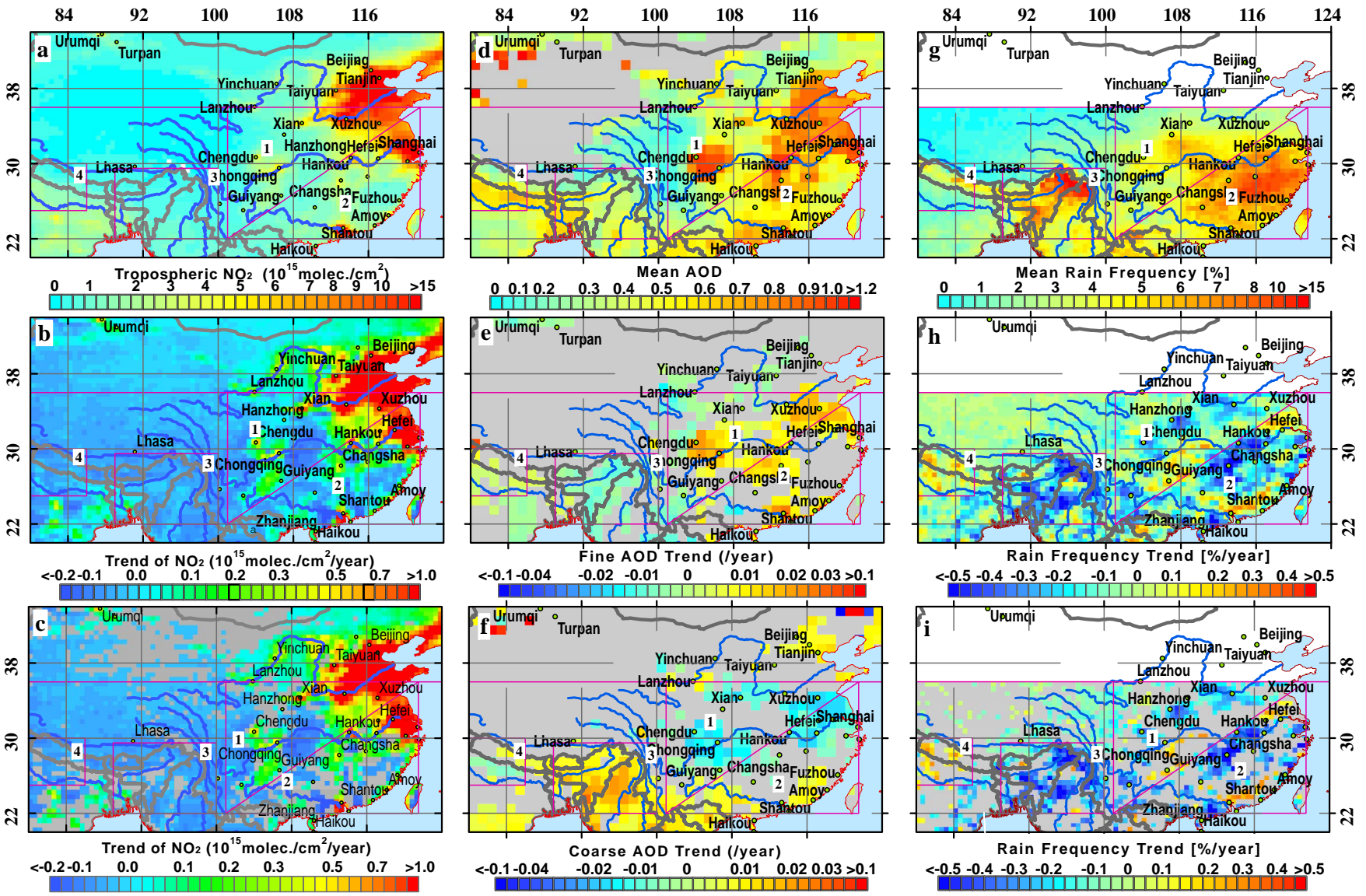

Fig. 3. Spatial distributions in spring during 1998-2009: (a) mean tropospheric $\mathrm{NO}_{2}$ column density, (b) tropospheric $\mathrm{NO}_{2}$ column density annual trend, (c) tropospheric $\mathrm{NO}_{2}$ column density annual trend with significant level above $95 \%$, (d) MODIS mean total Aerosol Optical Depth (AOD), (e) MODIS fine mode AOD annual trend, (f) MODIS coarse mode AOD annual trend, (g) mean TRMM PR rain frequency, (h) TRMM PR rain frequency annual trend, and (i) TRMM PR rain frequency annual trend with significant level above $95 \%$.

The spatial distribution of mean rain frequency in spring of 1998-2009 (Fig. 3g) in China was consistent with the precipitation distribution measured by the surface rain gauge network (Liu et al., 2005; Yang and Lau, 2004; Zhai et al., 2005). Precipitation occurred more frequently south of Yangtze River and along the India-Myanmar border. The spatial distributions of rain frequency trends were different from the mean rain frequency distribution (Figs. $3 \mathrm{~h}$ and i). It suggests that changes in rain frequency are not mainly caused by possible rain band shifts associated with large scale dynamical changes. The most significant reductions in rain frequency were observed over Eastern China, while no significant trends were detected over western China and even increasing trends were detected over some regions around the Nepal-India border. Based on the threshold of statistical significant level of $95 \%$, three regions show a distinguished trend in rain frequency: Eastern China, India-Myanmar region, and Nepal-India region (Fig. 3i). The first two regions showed a significant decreasing trend and the last region showed an increasing trend. In Eastern China, the sig- nificantly decreasing trends in precipitation frequency were detected at the industrial areas with rapid economic growth, rather than the areas with high mean rain frequency. Each region exhibited its own local characteristics of geography, pollution, aerosols, and precipitation frequency. For Eastern China, there were two rain frequency reduction bands: one in the Yellow River region and the other along the Yangtze River region. In the Yellow River rain frequency reduction band, where the largest coal-producing and consumption areas are located, the $\mathrm{NO}_{2}$ concentrations increased substantially over the past decade, accompanied by an increase of the fine mode AOD. In the Yangtze River rain frequency reduction band, there are many mega-cities, such as Shanghai, Nanjing, Wuhan, and Changsha. For the past decade the economic development resulted in severe pollution as indicated by the increasing trends in $\mathrm{NO}_{2}$ concentration and in the fine mode AOD. The spatial correlation between the increasing trend of $\mathrm{NO}_{2}$ concentrations (and the positive fine mode AOD trend) and the decreasing trend of rain frequency suggests that the two have some fundamental linkage. 

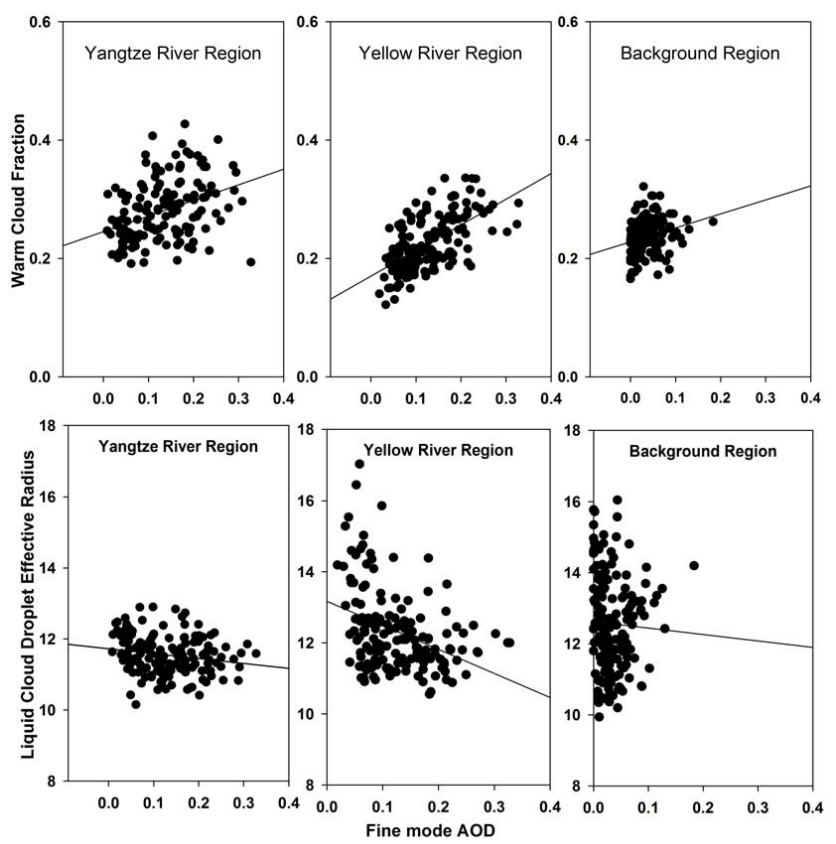

Fig. 4. The scatter plots of warm cloud fraction (upper panel) and liquid cloud droplet effective radius (lower panel) to the fine mode aerosol optical depth (AOD) over two polluted areas: the Yangtze River Region (30-34 $4^{\circ}$, $118-122^{\circ} \mathrm{E}$, left column) and Yellow River Region $\left(32-36^{\circ} \mathrm{N}, 111-115^{\circ} \mathrm{E}\right.$, middle column), and one pristine background area $\left(32-36^{\circ} \mathrm{N}, 100-104^{\circ} \mathrm{E}\right.$, right column).

Furthermore, an increase warm cloud fraction and a decrease liquid cloud droplet effective radius with fine aerosol loading are found in both bands, shown in Fig. 4. In contrast, the two variables showing a weaker correlation in background area with pristine atmosphere. Furthermore, the mean cloud effective radius over the polluted regions is smaller than that in the background region. The results corroborates that aerosol loading increases the amount of low-level cloudiness and inhibits the precipitation (Nakajima et al., 2001; Ramanathan et al., 2001).

The India-Myanmar Region is located to the south of Hengduan Mountain. Moisture air mass from the Indian Ocean will form orographic precipitation, which contributes to the high rain frequency in the region. Although the trend in $\mathrm{NO}_{2}$ concentration was not significant in the region, the enhancement of the coarse mode AOD in the upwind region was clearly evident. The increase of coarse AOD over the India-Myanmar region may be attributed by the large dust storms in northwest India, which starts in March-April in Rajasthan (Gautam et al., 2009a; Prospero et al., 2002). Additionally, the central dry zone of Myanmar is located in a subtropical semi-arid zone, which may also contribute to the increasing dust aerosol in this region. The observed decreasing trend in rain frequency along Hengduan Mountain reflects the impacts of enhanced aerosols on the orographic precipitation (Givati and Rosenfeld, 2004; Rosenfeld et al., 2007).
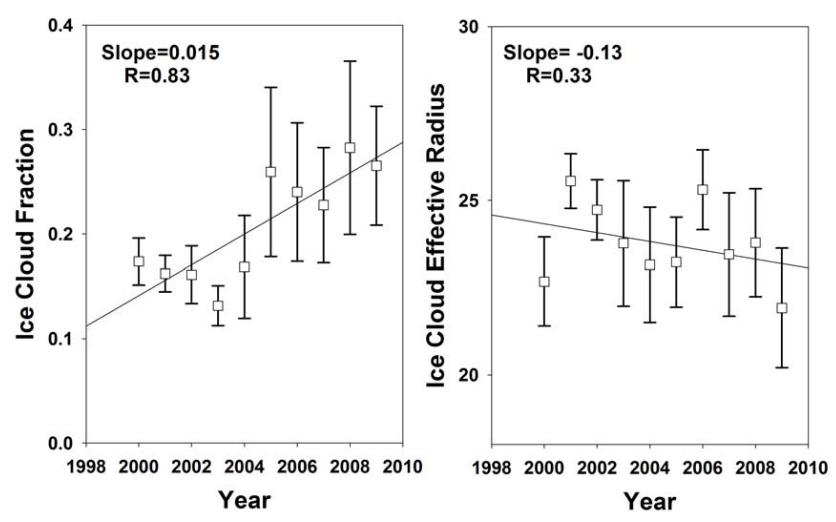

Fig. 5. The trend of ice cloud fraction and ice cloud effective radius over India-Myanmar region.

In the upwind region, the decreasing trend of rain frequency coincided well with the increasing trend in coarse mode AOD (Alpert et al., 2008; Halfon et al., 2009; van den Heever and Cotton, 2007). Also as shown in Fig. 5, there were an increasing trend of ice cloud fraction and a decreasing trend of ice cloud effective radius. As some of coarse aerosols may be insoluble particles, increased coarse mode aerosol may enhance heterogeneous nucleation processes and ice clouds, suppressing precipitation (DeMott et al., 2003; Rosefeld et al., 2001; Min et al., 2009). However, the trend of ice cloud water path over the India-Myanmar region is insignificant.

The only region with an increased precipitation frequency is located at the Nepal-India region, bordered by the Himalaya mountain range to the north. As discussed previously, since the high values of total mean AOD in this region during MAM are mostly contributed by the dust transport driven by pre-monsoon westerlies (Gautam et al., 2009b), it can be inferred that aerosol loading diminished during the study period when coarse mode AOD showed a negative trend. Thus there is an inverse relationship between the rain frequency increase and the aerosol reduction, which is consistent with the relationship of aerosol loading and rain frequency that revealed by the former two regions. However, the changes of both fine mode AOD and coarse mode AOD is much smaller than the trend of rain frequency, suggesting there may some other mechanism response for the rain frequency increment. Gautam et al. (2009a) suggested that the high value of aerosol loading during the pre-monsoon period (MAM) may induce a wetter season in early summer, since the land-sea temperature gradient was strengthened through the aerosol solar absorption. So the potential role of aerosol loading in rain frequency changes may also be supported in this region with rain frequency increasing despite a more rigorous analysis of the reciprocal relation between aerosol and precipitation is required by model studies and specific case investigation. 

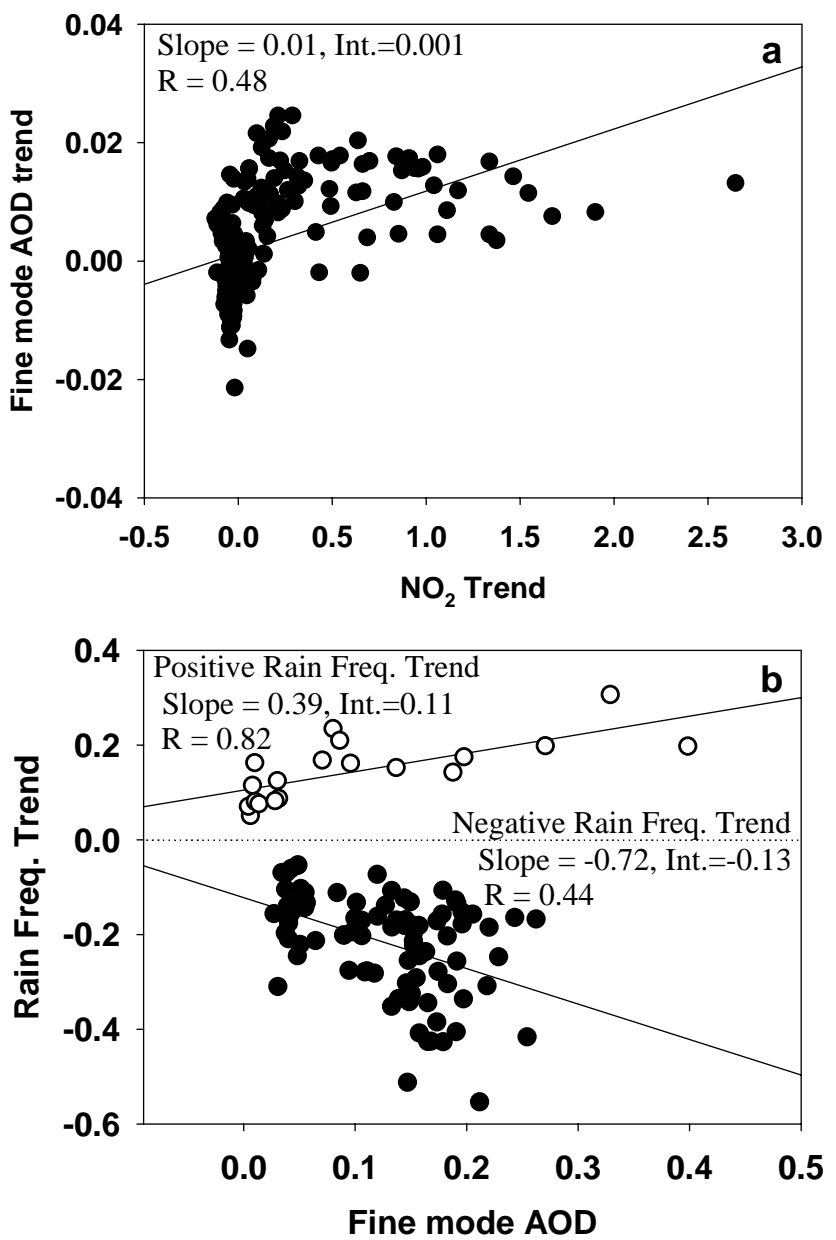

Fig. 6. (a) Scatter plot of the $\mathrm{NO}_{2}$ column concentration trends and the fine AOD trend; (b) Scatter plot of the rain frequency trend and the fine AOD.

To further illustrate the relationship of pollution and associate aerosols with rain frequency in the entire domain, we selected pixels with statistically significant trends in fine mode AOD, $\mathrm{NO}_{2}$, and rain frequency. As shown in Fig. 6a, there is a positive correlation coefficient of 0.48 at a $95 \%$ confidence level between the fine mode AOD trend and the $\mathrm{NO}_{2}$ trend. As discussed above, $\mathrm{NO}_{2}$ is a key precursor of secondary aerosols, especially in urban areas. Thus, an increase of $\mathrm{NO}_{2}$ emission is generally accompanied by an increase of fine aerosol particles. As shown in Fig. 6b, the grids with an increase of aerosol loading have a significant rain frequency reduction, with a correlation coefficient of 0.44 at $95 \%$ confidence level. Also, a strong positive correlation ( 0.82 at $95 \%$ confidence level) between the aerosol loading and the rain frequency trend was found in the grids with a significant increase of rain frequency. Most of these grids are located in the Nepal-India region.

To further illustrate the potential linkage of aerosols and rain frequency, the distribution of correlation coefficient be- tween the two is presented in Fig. 7. Due to the limited time span of Terra MODIS measurements, a low confidence level of $75 \%$ is set to filter out insignificant grids. As shown in Fig. 7, many negatively correlated grids between total AOD and rain frequency appeared in the Eastern China, IndiaMyanmar region, and Nepal-India region, which is consistent with our trend analysis. In general, the temporal variation of fine mode AOD is anti-correlated to that of coarse mode AOD. The consistency of the temporal variation of total AOD with its component, fine mode AOD or coarse mode AOD, depends on which component dominates the total aerosol variation. In the Eastern China, there are more grids that show the consistency of negative correlations of rain frequency with fine mode AOD and with total AOD, suggesting the fine mode AOD dominates in the region. In contrast, in India-Myanmar region, the negative correlation with the coarse mode AOD is similar to that with the total AOD, as the coarse mode AOD dominates the component of aerosol in the region.

However, changes in large-scale atmospheric circulation could result in observed changes in precipitation. The largescale factors that correlate well with precipitation are the column precipitable water $(\mathrm{PW})$ and divergence of water vapor transport (DWVT) in the atmosphere (Park et al., 2007; Qian et al., 2009). We used NCEP reanalysis data to investigate trends of the two factors in the selected regions. Although the resolution of NCEP reanalysis data is coarse at $2.5^{\circ} \times 2.5^{\circ}$, the regional features are evident. As shown in Fig. 8, the spatial distribution of the PW in spring shows statistically insignificant trends in all selected regions. Similarly, most regions have statistically insignificant trends in DWVT integrated from $1000 \mathrm{mb}$ to $500 \mathrm{mb}$ in spring, except for a few grid-points near north and south boundaries. It illustrates that the observed changes in precipitation were not related to PW and DWVT, the major dynamical factors that affect large scale precipitation change.

Similar spatial-temporal analysis of precipitation amount from TRMM PR illustrates much weaker regional features than those in rain frequency. It corroborates our finding in Shanghai that the changes in precipitation are more due to changes in precipitation occurrence than in precipitation amount (not shown here). Further, extensive studies on other seasons have been conducted. The spatial-temporal features of rain frequency in both summer and winter seasons showed a major cluster of decreasing trend pixels, associated with the mean rain frequency. It suggests those changes in rain frequency may be dominated by changes in monsoon dynamics. In fall, the spatial-temporal features of rain frequency had some but weaker coherence to the regional features of $\mathrm{NO}_{2}$ and aerosol trends than in spring. It may be partially due to some influences of monsoon dynamics, as the monsoon transit in fall is relatively short. 

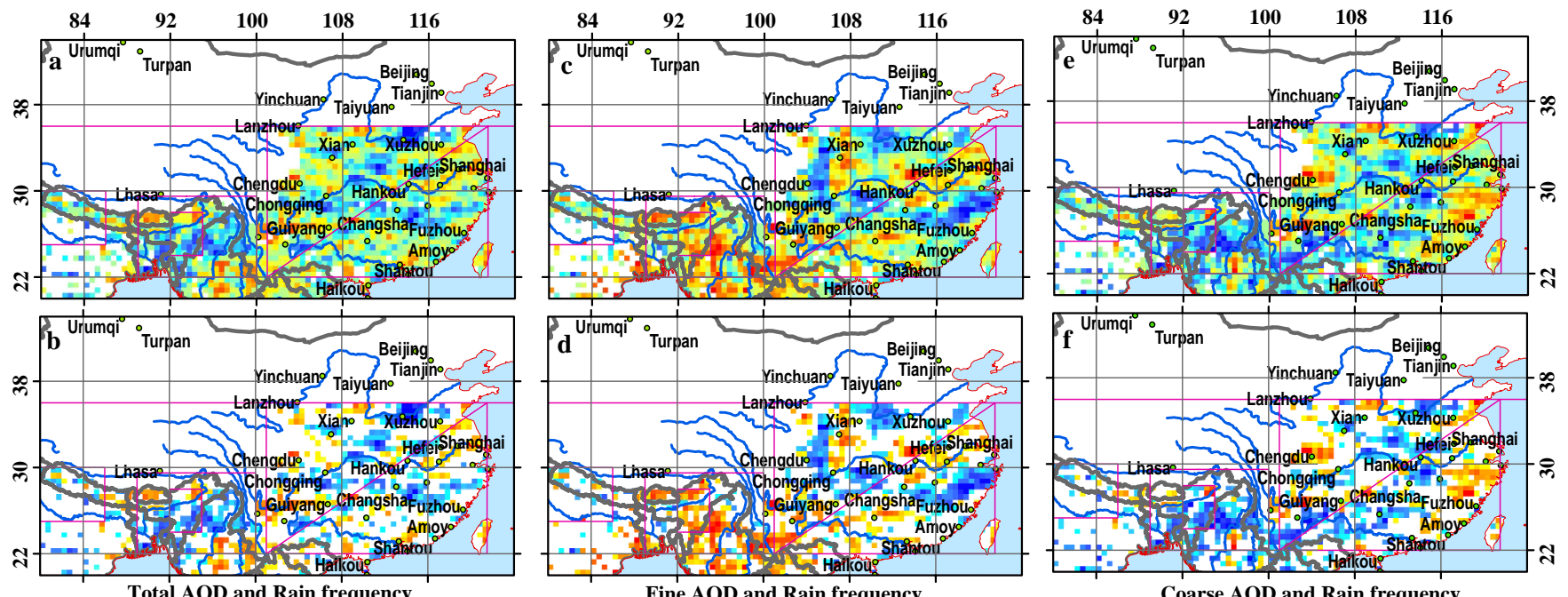

Fine AOD and Rain frequency

Correlation coefficient of AOD and Rain frequency

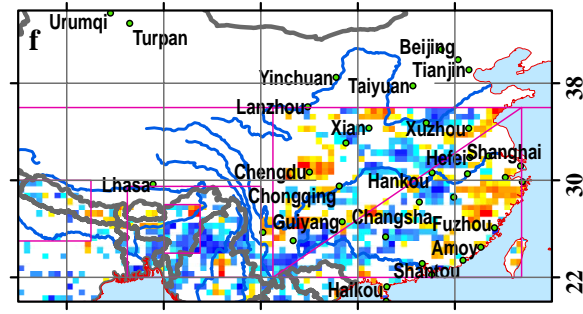

Coarse AOD and Rain frequency

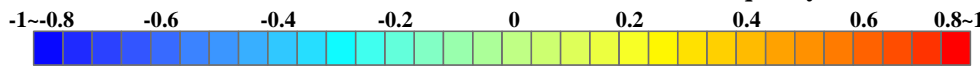

Fig. 7. The spatial distribution of correlation coefficient between rain frequency with AOD (a, b with only significant correlation coefficients shown, a $75 \%$ confidence level was taken); Fine mode AOD (c, d same with b); coarse mode AOD (e, $\mathbf{f}$ same with b).

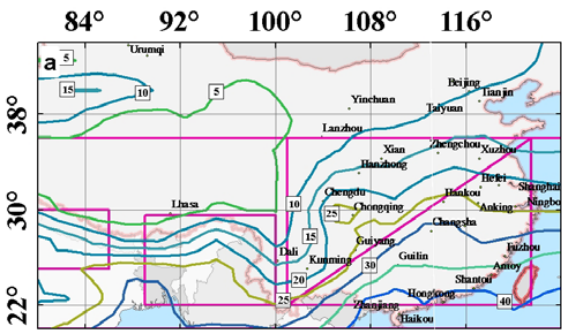

Mean Precipitable Water $\left(\mathrm{kg} \mathrm{m}^{-2}\right)$

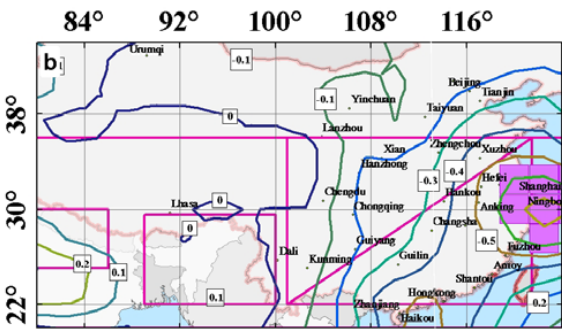

Trend of Precipitable Water $\left(\mathrm{kg} \mathrm{m}^{-2} \mathrm{yr}^{-1}\right)$

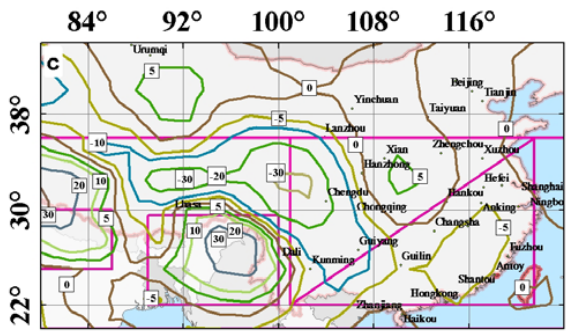

Mean Divergent Water Vapor Transport $\left(500-1000 \mathrm{mb}^{2} 10^{-5} \mathrm{~kg} \mathrm{~m}^{-2} \mathrm{~s}^{-1}\right)$

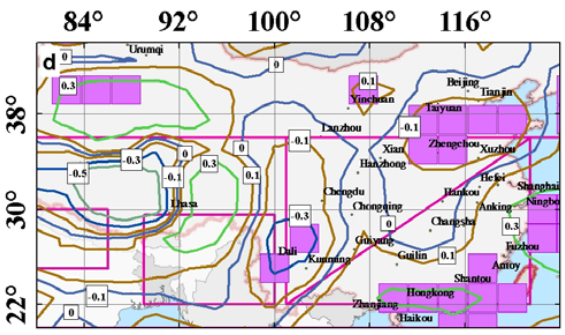

Trend of Divergent Water Vapor Transport $\left(500-1000 \mathrm{mb}^{-1} 10^{-5} \mathrm{~kg} \mathrm{~m}^{-2} \mathrm{~s}^{-1} \mathrm{yr}^{-1}\right)$

Fig. 8. Spatial distributions of column precipitable water (PW) and divergence of water vapor transport (DWVT), and their corresponding trends in spring during 1998-2009. The shaded grids are the trend with significant level above $95 \%$.

\section{Conclusions and discussion}

A spatial-temporal analysis has been conducted using satellite observed distributions of rain frequency, $\mathrm{NO}_{2}$ concentration, and aerosols in spring over East Asia. The growing anthropogenic emissions have led to increased air pollution, i.e., anthropogenic aerosol and its precursor gases which have reported in many previous studies ( $\mathrm{Lu}$ et al., 2010; Zhang et al., 2007) and also present in this study. More importantly, the overall feature emerged from the region-byregion analyses, including Eastern China, India-Myanmar border, and Nepal-India region, is that there is an inverse relationship between the rain frequency and the pollution and associated aerosols in spring. The climatically significant 
reduction of rain frequency is observed in the first two regions, where pollution and aerosols exhibit an increase trend. Also an increase trend of rain frequency is detected in the last region where aerosols decrease. Comparison between trends in rain frequency and in precipitation amount shows that the changes in precipitation are more due to changes in precipitation occurrence than in precipitation amount.

It is suggestive from the spatial-temporal inverse relationship of pollution and rain frequency at continental scale that there are possible climate effects of anthropogenic pollution on precipitation. Two possible pathways are speculated: (1) the increased $\mathrm{NO}_{2}$ and aerosols (soot particles in particular) enhance the absorption of solar radiation and stabilize the atmosphere, resulting in reduction of cloud formation and rain frequency; and/or (2) the enhancement of pollutionproduced $\mathrm{CCN}$ in addition to mineral dust from long-range transport further suppresses the rain frequency, as favored by topography, wind, and other meteorological conditions. However, aerosol effects on precipitation follow a chain of microphysical and thermodynamical processes that occur at shorter time scales. Other effects, such as urban effects and land surface modification, may contribute to the reduction of rain frequency at small local scale. Due to the potential uncertainty and bias associated with satellite measurements and relatively short duration of observation (10 years) in the current study, hence, more robust longer-term statistical study at various temporal and spatial scales and detailed modeling investigation are warranted to understand the physical causality of observed relationship between the rain frequency and the pollution and associated aerosols.

As the large-scale precipitation is controlled by evaporation, aerosols might influence it by surface cooling. In particular, aerosol microphysical effects can actually affect precipitation characteristics. Recent studies in North America also showed that the rain frequency was increased (Karl and Knight, 1998) while the tropospheric $\mathrm{NO}_{2}$ column was decreased (Richter et al., 2005). It further corroborates our finding that changes in rain occurrence may be associated with changes in pollution and associated aerosols. Furthermore, the suppression of precipitation leads to an increase in moisture and hygroscopic particles in the atmosphere. The increased amount of moisture and hygroscopic particles enhances regional haze if the moisture is relatively limited, or results in intense precipitation if water vapor in the atmosphere exceeds a threshold. This hypothesis is supported by the surface observations in China, i.e., increasing haze days (Chan and Yao, 2008; Ma et al., 2009); and an increasing trend of intensive precipitation frequency over the Yangtze River Basin (Zhai et al., 2005; Su et al., 2007).

These findings highlight the threat to vital water resources in polluted regions of the world, as in some industrialized areas of China and India, not only locally but also in the downwind regions. The importance of that is underlined by the realization that it is not high temperatures due to global warming but rather the lack of water that makes a region into an unlivable land. Particularly, any precipitation change in spring will significantly impact the stable crop production in the regions.

Acknowledgements. Many thanks to the TRMM, MODIS data processing team members and IUP-Bremen DOAS group for GOME and SCIAMACHY data. This research was supported by the Office of Science (BER), U.S. Department of Energy, Grant DE-FG02-03ER63531, and by the NOAA Educational Partnership Program with Minority Serving Institutions (EPP/MSI) under cooperative agreements NA17AE1625 and NA17AE1623. This work was also supported by the oversea scholar foundation of the China Scholarship Council and partially by the National Key Project of Basic Research of China (Grant Nos. 2006CB403704).

Edited by: J. Quaas

\section{References}

Albrecht, B. A.: Aerosols, Cloud Microphysics, and Fractional Cloudiness, Science, 245(4923), 1227-1230, 1989.

Allen, M. R. and Ingram, W. J.: Constraints on future changes in climate and the hydrologic cycle, Nature, 419(6903), 224-232, 2002.

Alpert, P., Halfon, N., and Levin, Z.: Does Air Pollution Really Suppress Precipitation in Israel?, J. Appl. Meteorol. Clim., 47(4), 933-943, 2008.

Bornstein, R. and Lin, Q.: Urban heat islands and summertime convective thunderstorms in Atlanta: three case studies, Atmos. Environ., 34(3), 507-516, 2000.

Carrico, C. M., Bergin, M. H., Shrestha, A. B., Dibb, J. E., Gomes, L., and Harris, J. M.: The importance of carbon and mineral dust to seasonal aerosol properties in the Nepal Himalaya, Atmos. Environ., 37(20), 2811-2824, 2003.

Chan, C. K. and Yao, X.: Air pollution in mega cities in China, Atmos. Environ., 42(1), 1-42, 2008.

Changnon, S. A., Huff, F. A., and Semonin, R. G.: METROMEX: A review and Summary, Am. Meteorol. Soc., Boston, MA, 1981.

Chow, S. D. and Chang, C.: Shanghai urban influences on humidity and precipitation distribution, GeoJournal, 8(3), 201-204, 1984.

Chu, D. A., Kaufman, Y. J., Ichoku, C., Remer, L. A., Tanr, D., and Holben, B. N.: Validation of MODIS aerosol optical depth retrieval over land, Geophys. Res. Lett., 29(12), 8007, doi:10.1029/2001GL013205, 2002.

Cotton, W. R. and Pielke, R. A.: Human Impacts onWeather and Climate, Cambridge University Press, New York, 1995.

Dell, C. W., Wentz, F. J., and Bennartz, R.: Cloud Liquid Water Path from Satellite-Based Passive Microwave Observations: A New Climatology over the Global Oceans, J. Climate., 21(8), 17211739, 2008.

DeMott, P. J., Sassen, K., Poellot, M. R., Baumgardner, D., Rogers, D. C., Brooks, S. D., Prenni, A. J., and Kreidenweis, S. M.: African dust aerosols as atmospheric ice nuclei, Geophys. Res. Lett., 30(14), 1732, doi:10.1029/2003GL017410, 2003.

Fowler, A. M. and Hennessy, K. J.: Potential Impacts of Global Warming on the Frequency and Magnitude of Heavy Precipitation, Nat. Hazards, 11(3), 283-303, 1995. 
Gautam, R., Hsu, N. C., Lau, K.-M., and Kafatos, M.: Aerosol and rainfall variability over the Indian monsoon region: distributions, trends and coupling, Ann. Geophys., 27, 3691-3703, doi:10.5194/angeo-27-3691-2009, 2009a.

Gautam, R., Liu, Z. Y., Singh, R. P., and Hsu, N. C.: Two contrasting dust-dominant periods over India observed from MODIS and CALIPSO data, Geophys. Res. Lett., 36, L06813, doi:10.1029/2008GL036967, 2009b.

Givati, A. and Rosenfeld, D.: Quantifying Precipitation Suppression Due to Air Pollution, J. Appl. Meteorol., 43(7), 1038-1056, 2004.

Gong, D. Y. and Wang, S. W.: The influence of ENSO on global and China's surface precipitation during recent 100 years, Chinese Science Bulletin, 44(3), 315-320, 1999.

Halfon, N., Levin, Z., and Alpert, P.: Temporal rainfall fluctuations in Israel and their possible link to urban and air pollution effects, Environ. Res. Lett., 4(2), 025001, doi:10.1088/17489326/4/2/025001, 2009.

Hand, L. M. and Shepherd, J. M.: An Investigation of Warm-Season Spatial Rainfall Variability in Oklahoma City: Possible Linkages to Urbanization and Prevailing Wind, J. Appl. Meteorol. Clim., 48(2), 251-269, 2009.

Heue, K.-P., Richter, A., Bruns, M., Burrows, J. P., v. Friedeburg, C., Platt, U., Pundt, I., Wang, P., and Wagner, T.: Validation of SCIAMACHY tropospheric $\mathrm{NO}_{2}$-columns with AMAXDOAS measurements, Atmos. Chem. Phys., 5, 1039-1051, doi:10.5194/acp-5-1039-2005, 2005.

Heymsfield, A. J. and McFarquhar, G. M.: Microphysics of INDOEX clean and polluted trade cumulus clouds, J. Geophys. Res., 106(D22), 28653-28673, 2001.

Hyer, E. J., Reid, J. S., and Zhang, J.: An over-land aerosol optical depth data set for data assimilation by filtering, correction, and aggregation of MODIS Collection 5 optical depth retrievals, Atmos. Meas. Tech., 4(3), 379-408, doi:10.5194/amt-4-379-2011, 2011.

IPCC: Observations: Surface and Atmospheric Climate Change, in: Climate Change 2007: The Physical Science Basis, Contribution of Working Group I to the Fourth Assessment Report of the Intergovernmental Panel on Climate Change, edited by: Solomon, S., Qin, D., Manning, M., Chen, Z., Marquis, M., Averyt, K. B., Tignor, M., and Miller, H. L., the Intergovernmental Panel on Climate Change, Cambridge, United Kingdom and New York, NY, USA, 2007a.

IPCC: Technical Summary, in: Climate Change 2007: The Physical Science Basis. Contribution of Working Group I to the Fourth Assessment Report of the Intergovernmental Panel on Climate Change, the Intergovernmental Panel on Climate Change, Cambridge, United Kingdom and New York, NY, USA, 2007b.

Ionov, D. V., Sinyakov, V. P., and Semenov, V. K.: Validation of GOME (ERS-2) NO2 vertical column data with groundbased measurements at Issyk-Kul (Kyrgyzstan), Adv. Space Res., 37(12), 2254-2260, 2006.

Junkermann, W., Hacker, J., Lyons, T., and Nair, U.: Land use change suppresses precipitation, Atmos. Chem. Phys., 9, 65316539, doi:10.5194/acp-9-6531-2009, 2009.

Kahn, R. A., Nelson, D. L., Garay, M. J., Levy, R. C., Bull, M. A., Diner, D. J., Martonchik, J. V., Paradise, S. R., Hansen, E. G., and Remer, L. A.: MISR Aerosol Product Attributes and Statistical Comparisons With MODIS, IEEE T. Geosci. Remote, 47, 12,
4095-4114, doi:10.1109/TGRS.2009.2023115, 2009.

Karl, T. R. and Knight, R. W.: Secular Trends of Precipitation Amount, Frequency, and Intensity in the United States, B. Am. Meteorol. Soc., 79(2), 231-241, 1998.

King, M. D., Menzel, W. P., Kaufman, Y. J., Tanre, D., Gao, B.C., Platnick, S., Ackerman, S. A., Remer, L. A., Pincus, R., and Hubanks, P. A.: Cloud and Aerosol Properties, Precipitable Water, and Profiles of Temperature and Humidity from MODIS, IEEE T. Geosci. Remote, 41, 442-458, 2003.

Koren, I., Kaufman, Y. J., Rosenfeld, D., Remer, L. A., and Rudich, Y.: Aerosol invigoration and restructuring of Atlantic convective clouds, Geophys. Res. Lett., 32(14), L14828, doi:10.1029/2005GL023187, 2005.

Landsberg, H. E.: The urban climate, Academic Press, New York, 277 pp., 1981.

Levin, Z., Ganor, E., and Gladstein, V.: The Effects of Desert Particles Coated with Sulfate on Rain Formation in the Eastern Mediterranean, J. Appl. Meteorol., 35(9), 1511-1523, 1996.

Levy, R. C., Remer, L. A., Kleidman, R. G., Mattoo, S., Ichoku, C., Kahn, R., and Eck, T. F.: Global evaluation of the Collection 5 MODIS dark-target aerosol products over land, Atmos. Chem. Phys., 10(21), 10399-10420, doi:10.5194/acp-10-103992010, 2010.

Liu, B., Xu, M., Henderson, M., and Qi, Y.: Observed trends of precipitation amount, frequency, and intensity in China, 1960-2000, J. Geophys. Res., 110, D08103, doi:10.1029/2004JD004864, 2005.

Lowry, W. P.: Urban effects on precipitation amount, Prog. Phys. Geogr., 22(4), 477-520, 1998.

Lu, Z., Streets, D. G., Zhang, Q., Wang, S., Carmichael, G. R., Cheng, Y. F., Wei, C., Chin, M., Diehl, T., and Tan, Q.: Sulfur dioxide emissions in China and sulfur trends in East Asia since 2000, Atmos. Chem. Phys., 10, 6311-6331, doi:10.5194/acp-106311-2010, 2010.

Luo, Y., Lu, D., Zhou, X., Li, W., and He, Q.: Characteristics of the spatial distribution and yearly variation of aerosol optical depth over China in last 30 years, J. Geophys. Res., 106(D13), doi:10.1029/2001JD900030, 2001.

Ma, J., Chen, Y., Wang, W., Yan, P., Liu, H., Yang, S., Hu, Z., and Lelieveld, J.: Strong air pollution causes widespread haze-clouds over China, J. Geophys. Res., 115(D18), D18204, doi:10.1029/2009JD013065, 2009.

Min, Q.-L., Li, R., Lin, B., Joseph, E., Wang, S., Hu, Y., Morris, V., and Chang, F.: Evidence of mineral dust altering cloud microphysics and precipitation, Atmos. Chem. Phys., 9, 3223-3231, doi:10.5194/acp-9-3223-2009, 2009.

Nakajima, T., Higurashi, A., Kawamoto, K., and Penner, J. E.: A possible correlation between satellite-derived cloud and aerosol microphysical parameters, Geophys. Res. Lett., 28(7), 11711174, doi:10.1029/2000GL012186, 2001.

New, M., Todd, M., Hulme, M., and Jones, P.: Precipitation measurements and trends in the twentieth century, Int. J. Clim., 21(15), 1889-1922, 2001.

Park, S.-C., Sohn, B.-J., and Wang, B.: Satellite Assessment of Divergent Water Vapor Transport from NCEP, ERA40, and JRA25 Reanalyses over the Asian Summer Monsoon Region, J. Meteorol. Soc. Jpn. Ser. II, 85, 615-632, 2007.

Prasad, A. K., Singh, S., Chauhan, S. S., Srivastava, M. K., Singh, R. P., and Singh, R.: Aerosol radiative forcing over the 
Indo-Gangetic plains during major dust storms, Atmos. Environ, 41(29), 6289-6301, 2007.

Prospero, J. M., Ginoux, P., Torres, O., Nicholson, S. E., and Gill, T. E.: Environmental characterization of global sources of atmospheric soil dust identified with the Nimbus 7 Total Ozone Mapping Spectrometer (TOMS) absorbing aerosol product, Rev. Geophys., 40(1), 1002, doi:10.1029/2000RG000095, 2002.

Qian, Y., Gong, D., Fan, J., Leung, L. R., Bennartz, R., Chen, D., andWang,W.: Heavy pollution suppresses light rain in China: Observations and modeling, J. Geophys. Res., 114, D00K02, doi:10.1029/2008JD011575, 2009.

Ramanathan, V., Crutzen, P. J., Kiehl, J. T., and Rosenfeld, D.: Aerosols, Climate, and the Hydrological Cycle, Science, 294(5549), 2119-2124, 2001.

Ramanathan, V., Chung, C., Kim, D., Bettge, T., Buja, L., Kiehl, J. T., Washington, W. M., Fu, Q., Sikka, D. R., and Wild, M.: Atmospheric brown clouds: Impacts on South Asian climate and hydrological cycle, P. Natl. Acad. Sci. USA, 102(15), 53265333, 2005.

Remer, L. A., Kaufman, Y. J., Tanre, D., Mattoo, S., Chu, D. A., Martins, J. V., Li, R. R., Ichoku, C., Levy, R. C., Kleidman, R. G., Eck, T. F., Vermote, E., and Holben, B. N.: The MODIS Aerosol Algorithm, Products, and Validation, J. Atmos. Sci., 62(4), 947973, 2005.

Remer, L. A., Kleidman, R. G., Levy, R. C., Kaufman, Y. J., Tanre, D., Mattoo, S., Martins, J. V., Ichoku, C., Koren, I., Yu, H. B., and Holben, B. N.: Global aerosol climatology from the MODIS satellite sensors, J. Geophys. Res., 113, D14S07, doi:10.1029/2007JD009661, 2008.

Richter, A. and Burrows, J. P.: Tropospheric $\mathrm{NO}_{2}$ from GOME measurements, Adv. Space Res., 29(11), 1673-1683, 2002.

Richter, A., Burrows, J. P., Nusz, H., Granier, C., and Niemeier, U.: Increase in tropospheric nitrogen dioxide over China observed from space, Nature, 437(7055), 129-132, 2005.

Rosenfeld, D.: Suppression of rain and snow by urban and industrial air pollution, Science, 287(5459), 1793-1796, 2000.

Rosenfeld, D., Rudich, Y., and Lahav, R.: Desert dust suppressing precipitation: A possible desertification feedback loop, P. Natl. Acad. Sci. USA, 98(11), 5975-5980, 2001

Rosenfeld, D., Dai, J., Yu, X., Yao, Z., Xu, X., Yang, X., and Du, C.: Inverse Relations Between Amounts of Air Pollution and Orographic Precipitation, Science, 315(5817), 1396-1398, 2007.

Rosenfeld, D., Lohmann, U., Raga, G. B., O’Dowd, C. D., Kulmala, M., Fuzzi, S., Reissell, A., and Andreae, M. O.: Flood or Drought: How Do Aerosols Affect Precipitation?, Science, 321(5894), 1309-1313, 2008.

Shepherd, J. M.: Evidence of urban-induced precipitation variability in arid climate regimes, J. Arid Environ., 67(4), 607-628, 2006.

Shepherd, J. M. and Burian, S. J.: Detection of Urban-Induced Rainfall Anomalies in a Major Coastal City, Earth Interact., 7(4), 1-17, 2003.

Shepherd, J. M., Pierce, H., and Negri, A. J.: Rainfall Modification by Major Urban Areas: Observations from Spaceborne Rain Radar on the TRMM Satellite, J. Appl. Meteorol., 41(7), 689701, 2002.

Singh, R. P., Prasad, A. K., Chauhan, S. S., Singh, S., and Holben, B.: Long-range transport of aerosols and their impact on the air quality of the Indo-Gangetic basin, paper presented at 36th
COSPAR Scientific Assembly, Beijing, China, 2006.

Small, J. D., Chuang, P. Y., Feingold, G., and Jiang, H. L.: Can aerosol decrease cloud lifetime?, Geophys. Res. Lett., 36, L16806, doi:10.1029/2009GL038888, 2009.

Stevens, B. and Feingold, G.: Untangling aerosol effects on clouds and precipitation in a buffered system, Nature, 461(7264), 607613, 2009.

Stevens, B. and Seifert, A.: Understanding macrophysical outcomes of microphysical choices in simulations of shallow cumulus convection, J. Meteorol. Soc., 86, 143-162, 2008.

Su, B., Jiang, T., Ren, G., and Chen, Z.: Trends of Extreme Precipitation over the Yangtze River Basin of China in 1960-2004, Advances in Climate Change Research, 3, 45-50, 2007.

Sun, Y., Zhuang, G., Wang, Y., Zhao, X., Li, J., Wang, Z., and An, Z.: Chemical composition of dust storms in Beijing and implications for the mixing of mineral aerosol with pollution aerosol on the pathway, J. Geophys. Res., 110, D24209, doi:10.1029/2005JD006054, 2005.

Tirado, M. C., Clarke, R., Jaykus, L. A., McQuatters-Gollop, A., and Franke, J. M.: Climate change and food safety: A review, Food Res. Int., 43(7), 1745-1765, 2010.

van den Heever, S. C., and Cotton, W. R.: Urban Aerosol Impacts on Downwind Convective Storms, J. Appl. Meteorol. Clim., 46(6), 828-850, 2007.

van der A, R. J., Peters, D. H. M. U., Eskes, H., Boersma, K. F., Van Roozendael, M., De Smedt, I., and Kelder, H. M.: Detection of the trend and seasonal variation in tropospheric $\mathrm{NO}_{2}$ over China, J. Geophys. Res., 111, D12317, doi:10.1029/2005JD006594, 2006.

Wang, Y., Zhuang, G., Zhang, X., Huang, K., Xu, C., Tang, A., Chen, J., and An, Z.: The ion chemistry, seasonal cycle, and sources of $\mathrm{PM}_{2.5}$ and TSP aerosol in Shanghai, Atmos. Environ., 40(16), 2935-2952, 2006.

Williams, E., Rosenfeld, D., Madden, N., Gerlach, J., Gears, N., Atkinson, L., Dunnemann, N., Frostrom, G., Antonio, M., Biazon, B., Camargo, R., Franca, H., Gomes, A., Lima, M., Machado, R., Manhaes, S., Nachtigall, L., Piva, H., Quintiliano, W., Machado, L., Artaxo, P., Roberts, G., Renno, N., Blakeslee, R., Bailey, J., Boccippio, D., Betts, A., Wolff, D., Roy, B., Halverson, J., Rickenbach, T., Fuentes, J., and Avelino, E.: Contrasting convective regimes over the Amazon: Implications for cloud electrification, J. Geophys. Res., 107(D20), 8082 doi:10.1029/2001JD000380, 2002.

Yang, F. and Lau, K. M.: Trend and variability of China precipitation in spring and summer: linkage to sea-surface temperatures, Int. J. Clim., 24(13), 1625-1644, 2004.

Yum, S. S. and Hudson, J. G.: Maritime/continental microphysical contrasts in stratus, Tellus B, 54(1), 61-73, 2002.

Zhai, P., Zhang, X., Wan, H., and Pan, X.: Trends in Total Precipitation and Frequency of Daily Precipitation Extremes over China, J. Clim., 18(7), 1096-1108, 2005.

Zhang, J. L. and Reid, J. S.: An analysis of clear sky and contextual biases using an operational over ocean MODIS aerosol product, Geophys. Res. Lett., 36, L15824, doi:10.1029/2009GL038723, 2009.

Zhang, J. L. and Reid, J. S.: A decadal regional and global trend analysis of the aerosol optical depth using a data-assimilation grade over-water MODIS and Level 2 MISR aerosol products, Atmos. Chem. Phys., 10, 10949-10963, doi:10.5194/acp-10- 
10949-2010, 2010.

Zhang, Q., Streets, D. G., He, K.,Wang, Y., Richter, A., Burrows, J. P., Uno, I., Jang, C. J., Chen, D., Yao, Z., and Lei, Y.: $\mathrm{NO}_{\mathrm{x}}$ emission trends for China, 1995-2004: The view from the ground and the view from space, J. Geophys. Res., 112(D22), D22306, doi:10.1029/2007JD008684, 2007.

Zhang, H. Q., Li, Y. H., and Gao, X. J.: Potential Impacts of LandUse on Climate Variability and Extremes, Adv. Atmos. Sci., 26(5), 840-854, 2009.
Zhang, X., Zwiers, F. W., Hegerl, G. C., Lambert, F. H., Gillett, N. P., Solomon, S., Stott, P. A., and Nozawa, T.: Detection of human influence on twentieth-century precipitation trends, Nature, 448(7152), 461-465, 2007.

Zhao, C., Tie, X., and Lin, Y.: A possible positive feedback of reduction of precipitation and increase in aerosols over eastern central China, Geophys. Res. Lett., 33, L11814, doi:10.1029/2006GL025959, 2006. 